\title{
Analysis of the Application of Total Quality Management in Lens Products in PT. XYZ
}

Amalia Utami Dewi ${ }^{1 *}$, Sugiyono Madelan ${ }^{1}$, Ahmad Badawi Saluy ${ }^{1}$

${ }^{1}$ Universitas Mercu Buana, Jakarta, Indonesia

DOI: $10.36348 / \mathrm{sb} .2021 . \mathrm{v} 07 \mathrm{i} 03.001$

| Received: 26.02.2021 | Accepted: 03.03.2021 | Published: 06.03.2021

*Corresponding author: Amalia Utami Dewi

\section{Abstract}

The purpose of this study was to determine the application of Total Quality. Management using the QC 7 Tools method at PT. XYZ. PT. Koito Indonesia is a company engaged in the manufacturing industry in the manufacture of lighting products. The analytical method used in this study is a quantitative method. PT. XYZ which has a very high Defect Rate in the Molding section. With a high Defect Rate situation in the Molding area it is necessary to reduce the high manufacturing defect so that it can improve the quality of the company measured in a Key Performance Indicator. Waste of defective products that occur in the Molding section is detrimental to the company and reduce the company's performance.

Keywords: Manufacturing Defect Rate, 7 Tools.

Copyright $\odot 2021$ The Author(s): This is an open-access article distributed under the terms of the Creative Commons Attribution 4.0 International License (CC BY-NC 4.0) which permits unrestricted use, distribution, and reproduction in any medium for non-commercial use provided the original author and source are credited.

\section{INTRODUCTION}

The lighting industry in Indonesia is growing very rapidly, such as PT. XYZ, PT. Ichikoh, and PT. Stanley Indonesia. The level of defect in the molding section, which is the initial part of the process in the production process, where the level of defect is still high based on the 2017 Key Performance Indicator report (Figure-1).

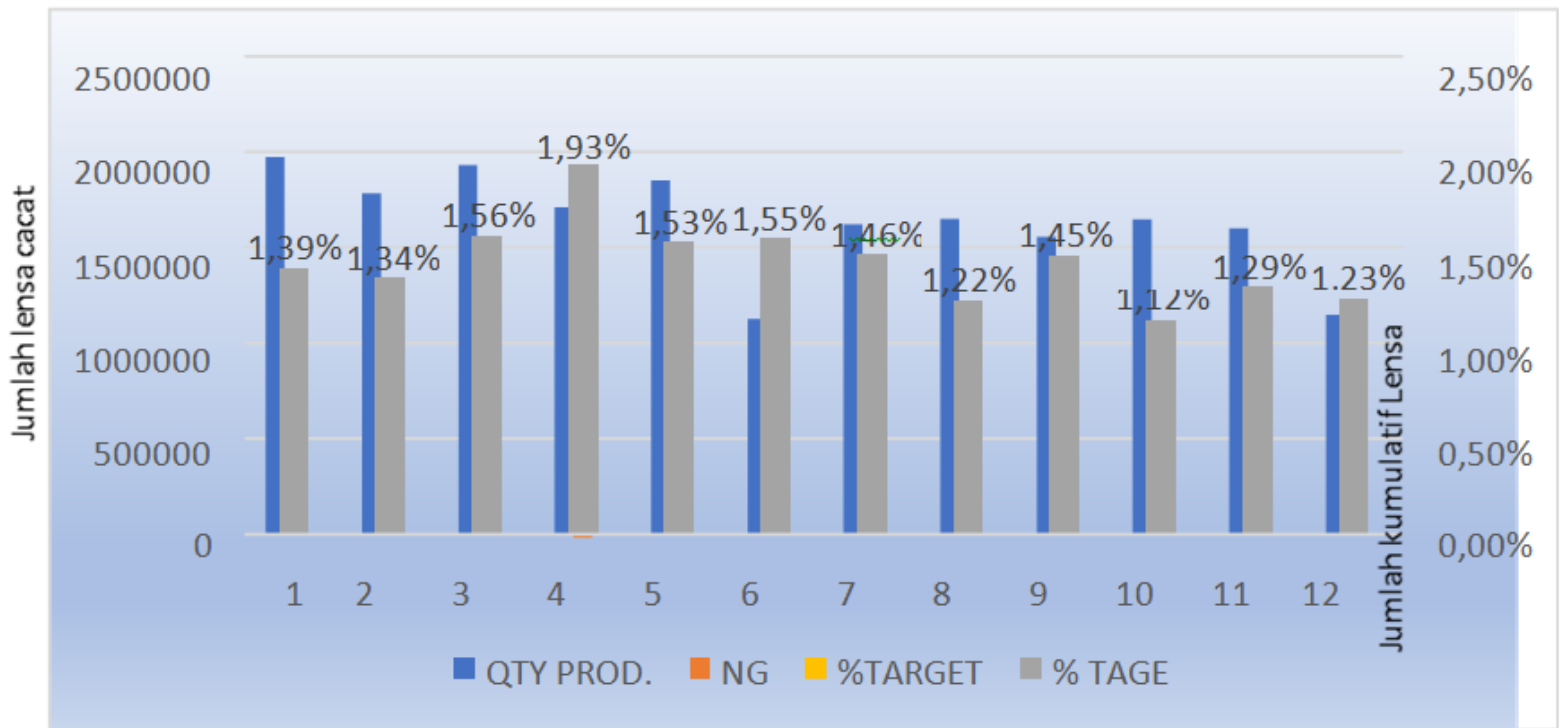

Fig-1: Percentage of Defective Products in Molding Parts 2017

Source: Injection quality report of PT. XYZ 
The Pareto diagram in Figure-2 shows that the highest percentage of defects is PC Clear (Polycarbonate Clear) with a percentage of $19.062 \%$. This proves that the process control in the Molding department has not been maximal, and the achievement of quality in 2017 is a very bad score so that it is necessary to make mprovements so that problems in process variations can be minimized.

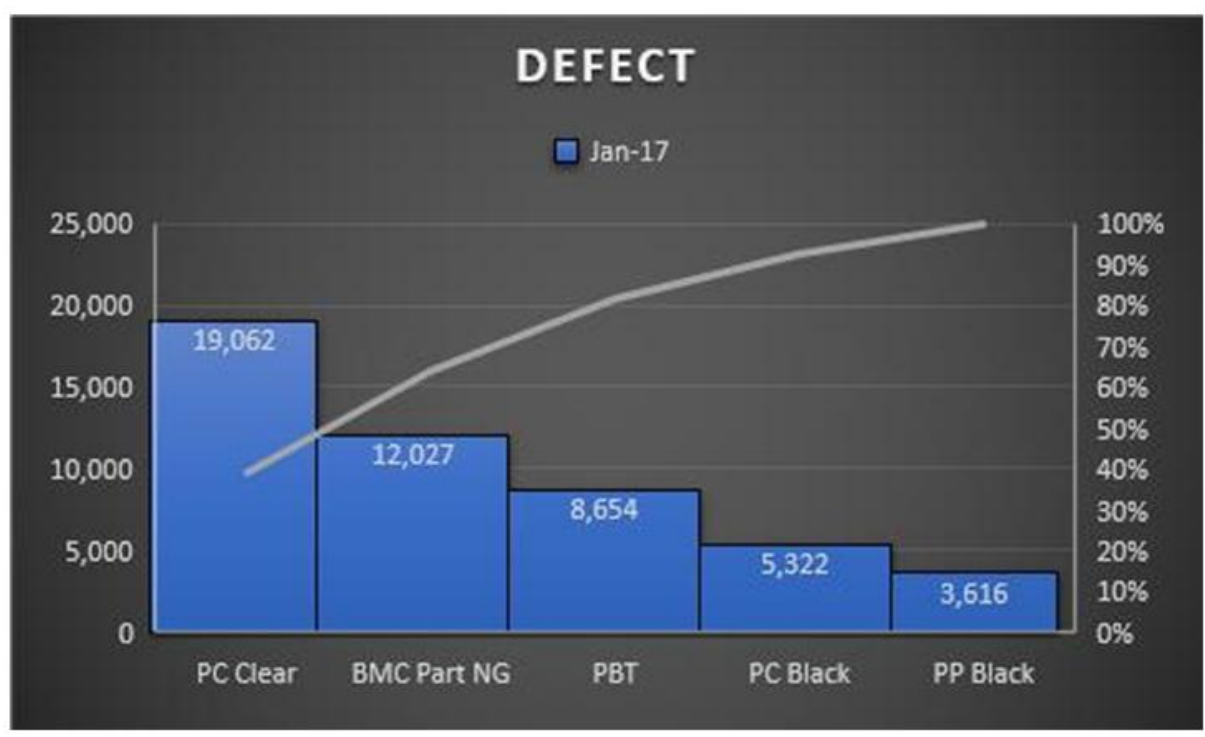

Fig-2: Pareto Diagram of the Highest 5 Defects Percentage in Molding 2017

Source: Molding Quality Report of PT. XYZ, 2017

The identification of problems in this research are: (1) the company has 5 big loose defects in the molding section, (2) factors that cause defects in the molding process, and (3) improvement efforts to improve the quality of the molding process. The research was carried out in the Indotaisei Industrial Estate, Cikampek - Karawang. The research was carried out at the Lens manufacturer at PT. XYZ. Identification and analysis are only carried out in the Molding process section. QC 7 Tools assessment is only carried out in the Molding process. Observations were made for the number of product failures produced in the period January to December 2017 at PT. XYZ. Observations were made in Jan - Dec 2018. The data taken for the QC 7 Tools approach is primary data.

\section{RESEARCH PURPOSES}

This study aims to get an overview of how the implementation of Total Quality Management (TQM) Using the QC 7 Tools PT. XYZ, and specifically aims at:

1. To determine the type of product that failed in the Molding section of PT. XYZ.

2. To find the main cause of the failure of the product in the Molding section of PT. XYZ.

3. To determine priority improvements in reducing the number of failed products in the Molding section at PT. XYZ.

\section{THEORITICAL REVIEW}

According to Heizer and Render [1], quality is the overall features and characteristics of a good or service that uses its ability to meet promised and implied needs. Prawirosentono [2] states that the quality of a product is the physical condition, function, and nature of a product in question that satisfies the tastes and needs of consumers according to the value of money that has been spent According to Joseph $\mathrm{M}$. Juran [3]: "Quality is fitness for use, quality is conformity with the goals or benefits". According to W. Edward Deming [4]: "Quality must be aimed at meetings current and future customer needs". According to Philip B. Crosby [5]: "Quality means conformance to requirements, quality is conformity to needs which include availability, delivery, reliability, maintainability, and cost effectiveness". According to Feigenbaum, V [6]: "Quality is the overall combination of product and service characteristics which include marketing, engineering, manufacture and maintenance through which products and services in use will be in accordance with customer expectations."

Defective products are products that do not meet predetermined quality standards but by incurring rework costs to repair them, these products can economically be refined into even better products [7] A product is called a defect if the product is not safe in use, does not meet certain conditions as expected by the user by considering various circumstances, especially regarding the appearance of the product, the intended use of the product and when the product is marketed. 




Gambar-3: Flow Chart Kerangka Pemikiran

\section{METHODOLOGY}

This research uses descriptive quantitative method. The population of this study is the quality report data of the Molding section from January 2018 to December 2018 for the total population of lens products is 2,034,546. The number of defect lens samples was 5428 units. All lens production data and defect lenses were used as research samples. Primary data is in the form of direct observation of the molding process at the company's production site. Secondary data were obtained from four managers, supervisors, group leaders, and operators, then conducted interviews.

\section{RESEARCH RESULT}

The company's production in December 2018 was 2,034,546 pcs of lenses with defects in PC Clear material as much as 2,200 pcs $(0.0011 \%)$ and in BMC material as many as 3,228 pcs $(0.0016 \%)$. The maximum number of defects is 389 . The minimum number of defects is 4 units.

The defective lens product rang is 389-4 = 385. The number of intervals is 6 classes. In Figure-3, it can be seen that the defective Lens product occurs a lot in the interval class on the left and also shows an imbalance in the amount of this damage. 


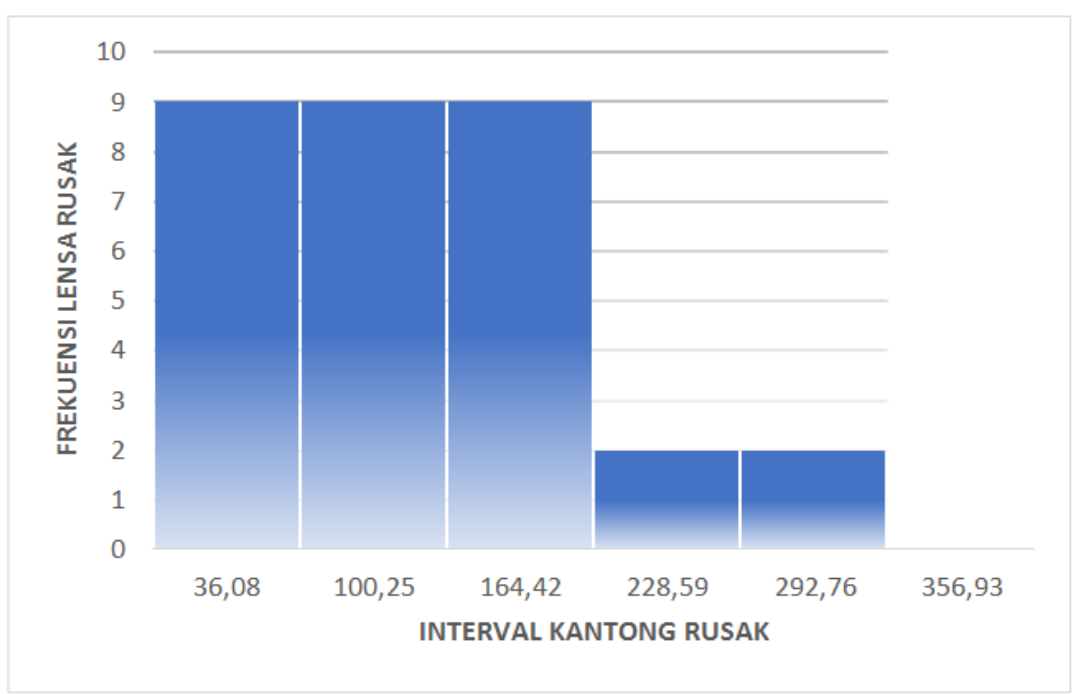

Fig-3: Histogram Graph of Damaged Lens Products

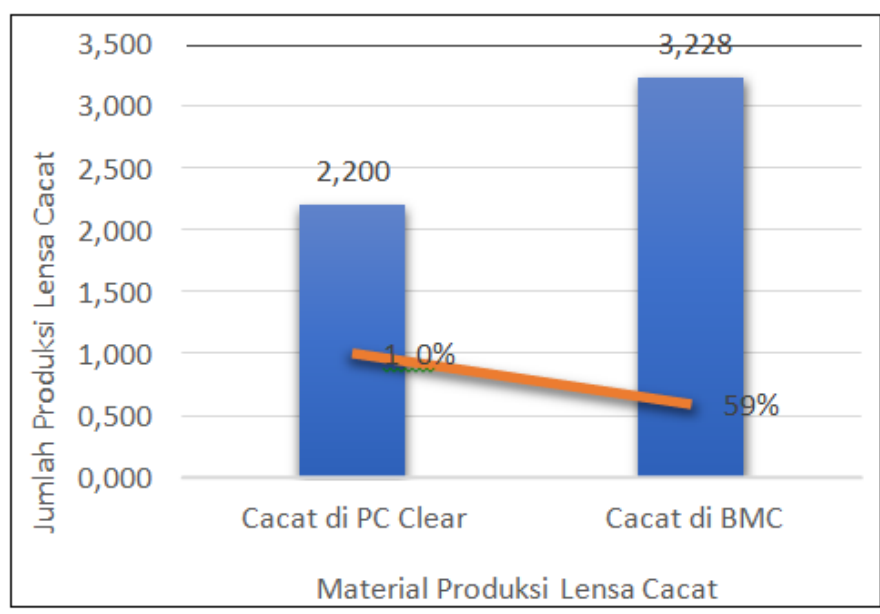

Fig-4: Pareto Defective Product Diagram

From the Pareto diagram above, it is known that the damaged cement bag product was more common in BMC than PC Clear. At BMC, 3,228 lens damage is equivalent to $59 \%$ of the total number of damaged lenses, and in PC Clear lens damage is 2,200 equivalent to $41 \%$ of the total damaged pouch.

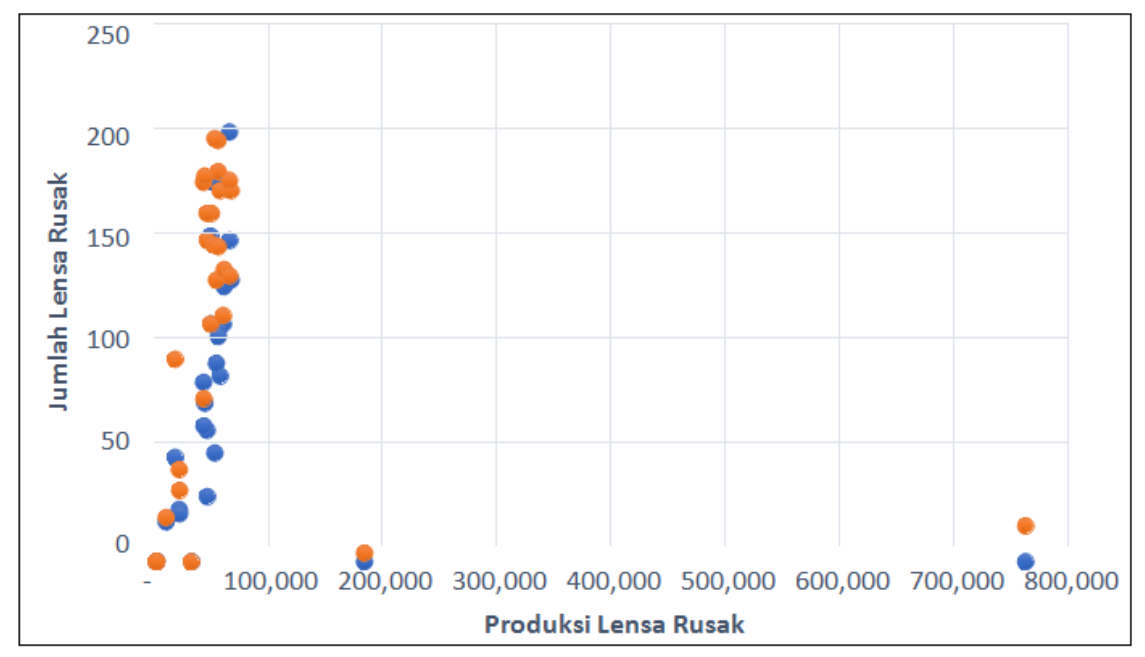

Fig-5: Graphic Scatter Diagram of Broken Lens Products 


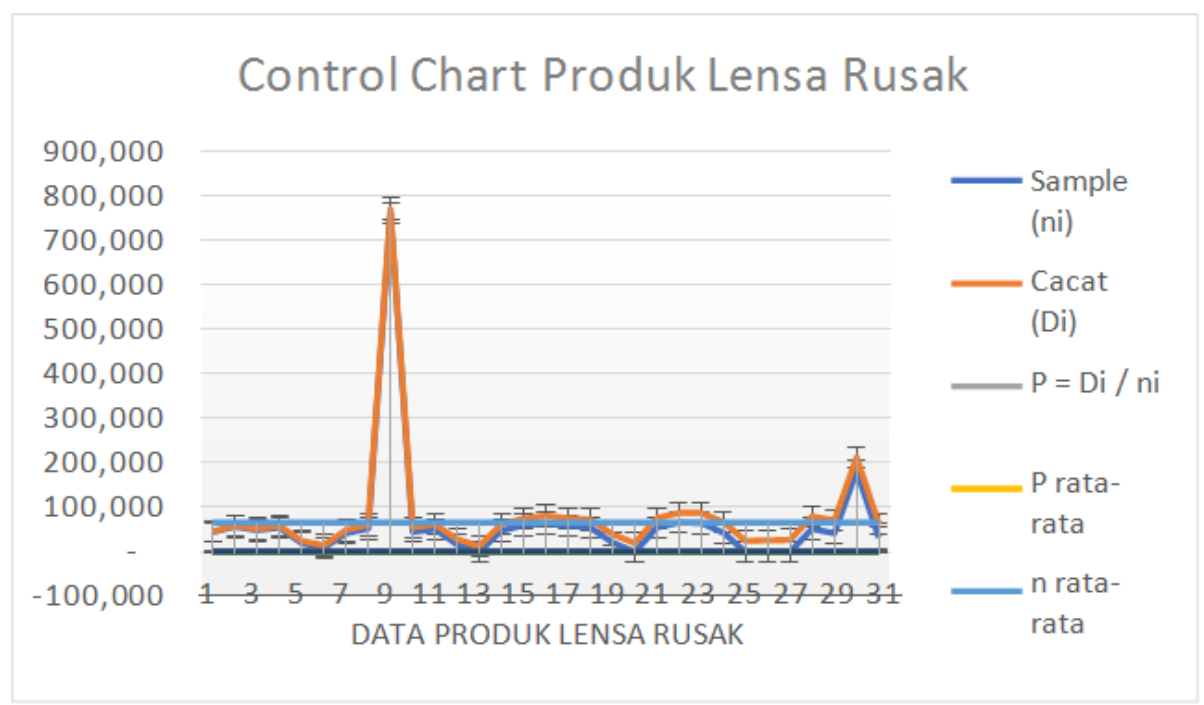

Fig-6: Control Chart for Damaged Lens



Fig-7: Histogram Graph of Damaged Lens Products at BMC

In Figure-7, it can be seen that the defective lens products at BMC occur a lot in the left-hand interval class and also show an imbalance in the amount of this damage.



Fig-8: Scatter Diagram for Defective Lens at BMC

From the diagram above, it can be seen that the number of damaged lenses produced at BMC varies, but it does not appear to be influenced by the number of lens production. 


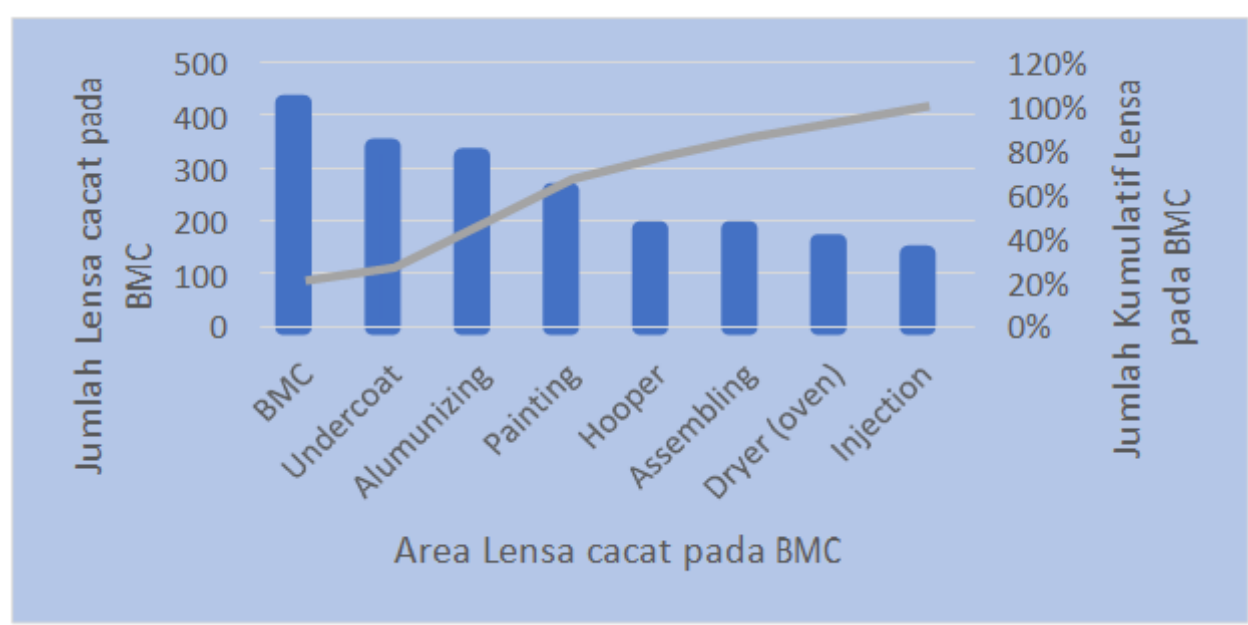

Fig-9: Pareto Lens Diagram Defects at BMC

From Figure-9 above, it can be seen that the lens products that occur in BMC occur mostly in BMC, Undercoat, Alumunizing, Hooper and others.

\section{DISCUSSION}

PT. XYZ uses 2 materials, namely PC Clear and BMC materials. Every time a part comes out, the lens quality is checked. Likewise, at BMC we can know the sequence of the process starting from the input material to the dryer to assembling and before moving to the warehouse the quality control is carried out.

There is damage to the two materials. Then from the daily data, I can also separate the damaged lenses for each production using BMC material only. Damage to the production of this lens, the author took from a production report written by a field officer in BMC materials, for the number of damaged lenses and depending on the problem he faced so that the lens was damaged.

The damaged lens is not evenly distributed, because many are on the left side and this is called an abnormal distribution. This abnormal lens production process is what the authors are looking for where the cause is, and will be looking for further. This we observe for the overall Lens Production and Lens Production at BMC. Damaged products and the amount of production have no relationship and the number of damaged lenses is purely due to this production process and not because of the amount of production. The Pareto diagram helps the author find the source of the problems that occur in the production process of this lens. Initially we will know which machines have a lot of damaged lens production, then what processes are in the machine. From the two Pareto diagrams above, it can be seen that the BMC material produces a lot of damaged lenses and the process in this BMC produces a lot of damaged lenses. So that the authors know that the process in BMC material is the biggest problem in producing damaged lenses.

\section{CONCLUSION}

After doing research at the lens manufacturer at PT. $\mathrm{XYZ}$, the authors conclude as follows:

1. Types of defects in lighting products in the Molding section of PT. XYZ is PC Clear, BMC, PBT, PC Black, and PP Black.

2. The root cause of the product failure at the Molding PT. XYZ namely in BMC is related to raw materials

3. Reducing the number of failures at the Molding PT. XYZ by using the one process one check method, that is, each process is responsible for the quality of the process.

\section{SUGGESTION}

For the management of PT. XYZ, the authors suggest:

1. Improvements to the root of the problem which is the author's findings in the near future can help management to find out whether there is a reduction in damaged lenses or not, so that they can take the next steps to make continuous repairs at PT. XYZ.

2. Quality tools such as these 7 tools can be applied in existing quality management in PT. XYZ to find out the quality process deviations that occur in the near future and repair them immediately. Because these 7 tools are easy to apply, the authors believe the management will have no difficulty in implementing them.

\section{REFERENCES}

1. Heizer, J. Bary Render. 2014. Operations Management Sustainability and Supply Chan Management.

2. Prawirosentono, S. (2007). Operation Management. Jakarta: Earth Literacy. 
Amalia Utami Dewi et al., Sch Bull, Mar, 2021; 7(3): 14-20

3. Juran, J. M. (2005). Pareto, lorenz, cournot, bernoulli, juran and others. Critical evaluations in business and management, 47.

4. Best, M., \& Neuhauser, D. (2005). W Edwards Deming: father of quality management, patient and composer. BMJ Quality \& Safety, 14(4), 310-312.

5. Crosby, P. B. (2005). Crosby's 14 steps to improvement. Quality Progress, 38(12), 60-64.

6. Feigenbaum, A. V. (2000). Integrated Quality Control. Volume 1. Third Edition. Jakarta: Erlangga.

7. Mulyadi, L., Stevens, C., Munro, S., Lingard, J., \& Bermingham, M. (2001). Body fat distribution and total body fat as risk factors for microalbuminuria in the obese. Annals of nutrition and metabolism, 45(2), 67-71.

8. Nuryanto, U. W., Mz, M. D., Sutawidjaya, A. H., \& Saluy, A. B. (2020). The Impact of Social Capital and Organizational Culture on Improving Organizational Performance. International Review of Management and Marketing, 10(3), 93-100.

9. Kemalasari, N., \& Saluy, A. B. Saudi Journal of Humanities and Social Sciences (SJHSS) ISSN 2415-6256 (Print)

10. Suzulia, M. T., \& Saluy, A. B. (2020). The Effect of Capital Structure. Company Growth, and Inflation on Firm Value With Profitability As Intervening Variable (Study on Manufacturing Companies Listed on BEI Period 2014-2018). Dinasti International Journal of Economics, Finance \& Accounting, 1(1), 95-109.

11. Saluy, A. B. (2018, November). Recruitment and profitability management (case study of primary sector companies listed on Indonesia Stock Exchange 2007-2016). In IOP Conference Series: Materials Science and Engineering (Vol. 453, No. 1, p. 012066). IOP Publishing

12. Saluy, A. B., Sujatmika, D., \& Kemalasari, N. (2019). Scholars Journal of Arts, Humanities andSocial Sciences. Work, 10(33), 3.
13. Saluy, A. B., PRAWIRA, B., \& BUNTARAN, D. F. A. A. The Influence of Leadership, Working Culture, and Working Environment for the Ministry.of Administrative Reform and Bureaucracy.

14. Sugiyono, (2005). Educational Research Methods, Quantitative Approaches, Qualitative, and R \& D. Alfabeta. BandungNuryanto, U. W., Mz, M. D., Sutawidjaya, A. H., \& Saluy, A. B. (2020). The Impact of Social Capital and Organizational Culture on Improving Organizational Performance. International Review of Management and Marketing, 10(3), 93-100.

15. Yamit, Z. (2013). Management of product and service quality. Yogyakarta: Ekonisia

16. Juboori. (2017). "Implementation Of Total Quality Management To Improve The Poultry Feed Manufacturing Processes". European Scientific Jurnal.

17. Sharmadan Suri. (2017). "Implementation of Quality Control Tools and Techniques in Manufacturing Industry for Process Improvement". Internasional Research Journal of Engineering and Technology. Volume 04.

18. Syed. (2015). "Improve the Quality of Tablets by Statistical Tools". IOSR Journal of Humanities and Social Science. Volume 20.

19. Fauzi, dan Siregar. (2017). "Perbaikan Kualitas Menggunakan Metode Seven Tools dan Fault Tree Analysis (FTA) di PT. XYZ”. Jurnal SENOPATI (Sustainability, Ergonomics, Optimization, and Application of Industrial Engineering).

20. Patel. (2014). "Application of Quality Control Tools in Taper Shank Drills Manufacturing Industry: A Case Study". International Journal of Engineering Research \& Application. Volume 04. 